\title{
Analysis of drug resistance in Helicobacter pylori by complete genome sequencing in Bama County, Guangxi, China
}

\author{
yanqiang huang ( $\square$ hyq77615@163.com ) \\ Xiao-Hua Li \\ Youjiang Medical University for Nationalities \\ Yong-Yi Huang \\ Youjiang Medical University for Nationalities \\ Xian-ke Luo \\ gastroenterology department \\ Li-juan Zhao \\ Youjiang Medical University for Nationalities \\ Ru-Jia Li \\ Youjiang Medical University for Nationalities \\ Yan-Chun Qin \\ Youjiang Medical University for Nationalities \\ Yuan-Yuan Dai \\ Youjing Medical University for Nationalities \\ Chun Qin \\ Youjiang Medical University for Nationalities \\ Hao Chen \\ Wannan Medical College
}

Research Center for the prevention and treatment of drug resistant microbial infecting https://orcid.org/0000-0002-3457-362X

\section{Research}

Keywords: Helicobacter pylori, resistance, complete genome, mechanism

Posted Date: November 2nd, 2020

DOI: https://doi.org/10.21203/rs.3.rs-96013/v1

License: (a) (1) This work is licensed under a Creative Commons Attribution 4.0 International License. Read Full License 


\section{Abstract}

The resistance rate of clinical Helicobacter pylori ( $\mathrm{Hp})$ isolates has increased, however, the mechanism of drug resistance is unclear. In this study, we isolated drug-resistant $\mathrm{Hp}$ strains isolated from different areas and different populations of China for genomic analysis. The aim of this study was to investigate drug resistance in Hp from Bama County, Guangxi, China. Minimal inhibitory concentrations (MICs) of clarithromycin, metronidazole and levofloxacin were determined and complete genome sequencing was performed with annotation. The presence of hp1181 and hp1184 genes was detected by RT-PCR. The relationships between hp1181, hp1184 and clarithromycin resistance were confirmed by gene mutation and drug-resistant strains. Three drug-resistant $\mathrm{Hp}$ strains were isolated from patients with gastritis in Bama County. The strains showed a high degree of homology with hp26695 through complete genome detection and identification. Differences in genome sequences, gene quantity and gene characteristics were detected amongst the three strains. Prediction and analysis of the function on drug-resistant genes indicated that the RNA expression of hp1181 and hp1184 increased in the three strains that were the same in the artificially induced clarithromycin-resistant bacteria. After gene knockout, the drug sensitivity of the strains increased significantly. In summary, The expressions of the genes hp1184 and hp1181 were associated with clarithromycin resistance in the Hp from Bama, Guangxi.

\section{Introduction}

Helicobacter pylori $(\mathrm{Hp})$ is recognized as an important human pathogen that colonizes the gastric mucus resulting in superficial gastritis, atrophic gastritis and gastric cancer ${ }^{[1-3]}$. Present treatments for $\mathrm{Hp}$ infection include proton pump inhibitors or bismuth in combination with amoxicillin or metronidazole and clarithromycin ${ }^{[4-5]}$. The rate of drug resistance is increasing due to a wide range of use of antibiotics and high resistance rates to clarithromycin, metronidazole and levofloxacin are associated with the failure of $\mathrm{Hp}$ eradication ${ }^{[6-8]}$. The World Health Organization (WHO) gave clarithromycin-resistant $\mathrm{Hp}$ as a high priority bacterium for antibiotic research and development ${ }^{[9]}$.

At present, the mechanism of antibiotic resistance of $\mathrm{Hp}$ is not completely understood ${ }^{[10-11]}$. It is widely accepted that the resistance to these antimicrobials is related to mutations in $\mathrm{Hp}$ gene: clarithromycin-resistant strains present three-point mutations in the region of domain $\mathrm{V}$ of 23S ribosomal RNA (rRNA): A2142G, A2142C and A2143G ${ }^{[12-13]}$. In addition to the mutations, the efflux pump cluster is also involved in the development of resistance to clarithromycin ${ }^{[14-15]}$. Moreover, there may be gene mutation sites that are not yet known and so the mechanism of drug resistance warrants further study.

We isolated, cultured Hp from the population in Bama County, which is a township known for the longevity of its residents in Guangxi, and randomly selected three strains of multiple drug-resistant $\mathrm{Hp}$ with resistance to clarithromycin. Complete genome sequences were analyzed to ascertain the genomic characteristics of the strains and to reveal the underlying mechanism of drug resistance in $\mathrm{Hp}$.

\section{Material And Methods}

\section{Isolation and culture of $\mathrm{Hp}$}

This study had received a strict medical ethics review from Youjiang Medical University for Nationalities. Written informed consent was obtained from each patient. Gastric mucosa tissue samples were collected from the People's Hospital of Bama Yao Autonomous County in patients' gastric body and pylorus with gastritis or gastric ulcers. Isolation and culture of Hp were performed at the Prevention and treatment Research Center for Resistance Microbiological, Youjiang Medical University for Nationalities. Patients investigated had not taken any antibiotics for at least four weeks before examination. The isolation and identification of $\mathrm{Hp}$ were performed as previously described ${ }^{[16-17]}$. The culture conditions used Columbia agar plates containing $5 \%$ fresh defibrinated sheep blood. The microaerophilic conditions included $5 \% 02$, $10 \% \mathrm{CO} 2$ and $85 \% \mathrm{~N} 2$ at $37^{\circ} \mathrm{C}$ for $3 \sim 5$ days. Suspicious colonies were confirmed by Gram stain, urease, oxidase, catalase activity testing and urease gene PCR testing.

\section{Antibiotic susceptibility testing}

The antibiotic resistance of $\mathrm{Hp}$ was measured by dilution methods with reference to the protocols of the Clinical and Laboratory Standards Institute (Wayne, PA, USA) ${ }^{[18]}$. Briefly, the concentration of $\mathrm{Hp}$ was regulated to be $1 \times 10^{6} \mathrm{CFU} / \mathrm{ml}$ and incubated at $37^{\circ} \mathrm{C}$ for $3 \sim 5$ days under microaerophilic conditions. After incubation, the plates were visually examined and the MIC was determined to be the lowest concentration that resulted in no turbidity. Metronidazole (Aladdin, d1707126), amoxicillin (Xiansheng pharmaceutical, 02-170404), levofloxacin (Shandong Lukang Pharmaceutical Group Saite Co., Ltd, 160608), clarithromycin (Yangzi River Pharmaceutical Group Co., Ltd 17111641) were also used.

\section{Complete genome testing and analysis}

Drug-resistant strains were selected and sent to the Shenzhen Huada Gene Co., Ltd. for complete genome analysis. After the DNA samples were delivered, the quality of the samples was tested and then used to construct a BSlibrary. The purified genomic DNA samples including 
genomic DNA, bacterial artificial chromosomes or long-length PCR products were sheared into smaller fragments by CovarisS/E210 or using a Bioruptor. The overhangs resulting from fragmentation were converted into blunt ends using T4 DNA polymerase, Klenow Fragment and T4 Polynucleotide Kinase. After adding an 'A' base to the 3 ' end of the blunt phosphorylated DNA fragments, adapters were ligated to the ends of the DNA fragments. The desired fragments were purified though gel-electrophoresis, selectively enriched and amplified by PCR. The index tag was introduced into the adapter at the PCR stage as appropriate and a library quality test was performed. Finally, the qualified BSlibrary was used for sequencing. Genomic component and gene function analyses were performed including gene prediction, tRNA, sRNA, genes annotation and the predicted open reading frames (ORFs) by GO.

\section{Drug resistance gene detection}

Drug resistance genes were predicted based on the results of the complete genome sequence analysis and selected for detection by RT-PCR. The reaction for cDNA synthesis was held at $25^{\circ} \mathrm{C}$ for $10 \mathrm{~min}, 42{ }^{\circ} \mathrm{C}$ for $60 \mathrm{~min}$ and $99{ }^{\circ} \mathrm{C}$ for 5 min. The reaction consisted of 32 cycles with each cycle composed of $1 \mathrm{~min}$ at $95^{\circ} \mathrm{C}, 4 \mathrm{~min}$ at $56^{\circ} \mathrm{C}$ and $7 \mathrm{~min}$ at $70{ }^{\circ} \mathrm{C}$. After a final extension of $15 \mathrm{~min}$ at $72{ }^{\circ} \mathrm{C}$, the RT-PCR products were visualized by electrophoresis on $1 \%$ agarose gel and $15 \%$ acrylamide gel with a 200 -bp ladder size marker.

\section{Knockout of mutant genes}

HP1181 and HP 1184 knockout mutants were constructed by insertion of the KAN resistance cassette. Double-knockout mutants were made by natural transformation of the KAN resistance cassette with pBSII KS (as presented by Bi Hongkai, Laboratory of Nanjing Medical University) containing an internal fragment interrupted with a cat cassette from pAV35, with selection for both KAN- and CHL-resistant colonies. Insertion of the KAN and cat resistance cassette at the desired locations in the Hp putative efflux genes was confirmed by PCR.

\section{Induction of drug resistance}

The MIC of clarithromycin to Hp26695 was detected. Drug resistance was induced by 1/4MIC. The culture medium was changed every two days and MIC was detected every four days. The concentration of induced drug was changed with MIC.

\section{Results}

\section{Bacterial resistance}

Three drug-resistant strains isolated and identified by Gram stain, urease, oxidase, catalase activity testing, and urease gene PCR testing: the drug resistance information of these strains is summarized in Table 1.

\section{Bacterial sequence information}

Based on the valid data from the previous sequencing platform, the CleanData could be assembled for each sample and the optimal assembly results were obtained after multiple adjustments. The assembly sequence was analyzed by correcting single base, circular judgment and plasmid comparison. The results of the genome assembly statistics of each sample are shown in Table 2 . These three strains have been uploaded to the NCBI Biosample database: Hpbs1(https://www.ncbi.nlm.nih.gov/biosample/?term=SAMN10461767)

Hpbs2(https://www.ncbi.nlm.nih.gov/biosample/?term=SAMN10663081), and Hpbs3(https://www.ncbi.nlm.nih.gov/biosample/? term=SAMN10663175),

\section{Gene information}

Gene prediction was applied to determine gene composition. The statistics are shown in Table 3 below.

\section{Circular genome analysis}

GC skew analysis was performed using $(G-C) /(G+C)$ calculations based on Genomic sequences of sequenced strains. The results of gene distribution, ncRNA distribution and gene annotation are demonstrated in Fig. 1. Hpbs 1 had 835 genes, 26 tRNAs, 6 rRNAs, 2 sRNAs in a positive chain. It also had 736 genes, 10 tRNAs, 0 rRNA, 5 sRNAs in negative chain and 157 repeats without positive or negative chain. There are 943 genes, 26 tRNAs, 6 rRNAs, 3 sRNAs, 849 genes, 10 tRNAs, 0 rRNA, 3 sRNAs, and 153 repeats in Hpbs2; 869 genes, 26 tRNAs, 6 rRNAs, 3 sRNAs, 863 genes, 10 tRNAs, 0 rRNA, 3 sRNAs, 155 repeats in Hpbs3.

\section{Gene annotation}

Functional annotation was accomplished by analysis of protein sequences. We aligned genes with databases to obtain their corresponding annotations. To demonstrate the biological meaning, the highest quality alignment result was chosen as a gene annotation. Functional 
annotation was completed by blasting genes with different databases. In this project we have finished P450, VFDB, ARDB, CAZY, SWISSPROT, NOG, COG, CARD, NR, DBCAN, T3SS, TREMBL, IPR, PHI, KEGG, GO, KOG...17 databases annotations. The annotation results are shown in Tables 4 and 5 .

\section{Analysis of drug resistance gene database}

The drug resistance gene numbers of three strains were different in the CARD drug resistance database, which are 14, 13 and 15 genes, respectively. However, after sorting, it was found that some genes were repetitive. The specific numbers and characteristics of genes are shown in the Tables 6 and 7. NP_207975.1 and NP_207972.1 were efflux pump genes of 26695 strain, i.e. hp1181 and hp1184 genes. Their drug resistance was verified by RT-PCR as illustrated in Fig. 2. After knocking out the drug resistance gene, drug sensitivity was significantly improved as shown in Fig. 3.

\section{Identification of 23S rRNA gene mutations}

Three strains were resistant to clarithromycin, so we analyzed and identified the sites of clarithromycin-resistant mutations. We found that three strains had mutations in A2142G, A2143G, G2144T, and some had mutations in other sites, as shown in Table 8.

\section{Gene mutation induced in drug-resistant strains}

After induction with clarithromycin, Hp26695 drug resistance was enhanced on the 12th day, reached the highest level on day 16 and increased to $8 \mu \mathrm{g} / \mathrm{ml}$ on the 24th day. The expressions of hp1181 and hp1184 were also increased with increasing clarithromycin resistance, especially hp1184, as shown in Fig. 4. Only A2142G and A $2143 \mathrm{G}$ mutations were detected in 23S RNA, with no other mutation sites being found囚as shown in Table 9. These data indicated that these two genes may be involved early in the regulation of clarithromycin resistance.

\section{Discussion}

The treatment of $\mathrm{Hp}$ remains based on bismuth tetralogy at present. Hp is eradicated clinically using common antibiotics including clarithromycin, amoxicillin, metronidazole, tetracycline and levofloxacin star. However, in recent years, the growing rate of antibiotic resistance has resulted in the failure of Hp eradication ${ }^{[19-20]}$. The most serious resistance has developed to drugs including metronidazole, clarithromycin, and levofloxacin star. The common mechanisms of bacterial resistance are the production of inactivated enzymes, change in the target position of antibacterial drugs, change in the permeability of bacterial outer membrane, effects on the active outflow system, formation of bacterial biofilm and cross resistance ${ }^{[21-23]}$. There are some differences in the mechanisms of drug resistance of each kind of bacteria, however, the same kind of bacteria still have different resistances to the same antibiotic in different areas ${ }^{[24]}$. The mechanism of drug resistance of $\mathrm{Hp}$ remains unclear and needs further study.

We selected drug-resistant strains using metronidazole, clarithromycin and levofloxacin for genome sequencing analysis. We found that there were no significant differences from the number of drug-resistant genes in the CARD database. This may be because two kinds of antibiotic resistance can develop and the drug-resistant genes in Hp are mainly hp1181 and hp1184. hp1181 is putative NDA translocase, related to the major facilitator superfamily, and is an integral membrane protein; hp1184 belongs to the MATE family, another translocase, resulting in the aforementioned susceptibility. These can contribute to resistance via a multi-drug resistance efflux protein, active-efflux of antibiotics and other efflux pump genes, such as HefA. After knockout of these two genes, the MICs of the drugs were significantly decreased and the sensitivity increased. It is noteworthy that in addition to these two genes, the GE2270A gene of Enterococcus and Mura gene of E. coli also show a correlation. It is likely that the drug-resistant plasmids of other strains invade Hp through transformation or other mechanisms. Bacteria other than $\mathrm{Hp}$ in the gastric mucosa of patients indirectly confirm this view. The main reason for this may be long-term acid resistant treatment, gastric erosion, or intestinal bacterial reflux. This will lead to drug resistance becoming more difficult to prevent and control, so we must attach great importance thereto. In addition, all three strains have clarithromycin resistance. The mechanism of resistance to clarithromycin is mainly reflected in the mutations A2142G, A2143G, G2144T. In addition, it is common that there are several mutations in the same strain.

hp1181 and hp1184 are related to multi-drug resistance and also to clarithromycin resistance, which has been previously reported in the literature $^{[25-26]}$. The RNA expressions of hp1181 and hp1184 were increased with the emergence of clarithromycin resistance with hp1184 showing the fastest increase. Therefore, these genes are also involved in the regulation of drug resistance and may be one of the mechanisms of $\mathrm{Hp}$ resistance to clarithromycin. Compared with the clinical isolates, $23 \mathrm{~S}$ RNA mutation sites of Hp were less frequent in artificially induced strains that had only $\mathrm{A} 2142 \mathrm{G}$ and $\mathrm{A} 2143 \mathrm{G}$ mutations. These may be due to the single factor of artificial induction that is not as complex as human stomach environment. More importantly, hp1184 mutation may be the earliest and most persistent response to clarithromycin resistance, and it may be the main target gene for the prevention and treatment of clarithromycin resistance. 
The genetic characteristics of multi-drug-resistant strains in this area were preliminarily identified: the relationship between hp1181, hp 1184 and clarithromycin resistance was demonstrated through genome sequencing analysis and gene function identification to drug-resistant $\mathrm{Hp}$ from Bama County, Guangxi Province. Our study further provided an improved experimental basis for the prevention and treatment of drug resistance of $\mathrm{Hp}$.

\section{Declarations}

Supported by: National Natural Science Foundation of China, No.81760739 and No. 31460023 . Special fund projects for guide local science and technology development by the China government(GUIKEZY20198004). The the Scientific Research Foundation for PhD of Wannan Medical College (grant WYRCQD2019010)

\section{References}

1. Yoon K, Kim N, Lee JW, Yoon H, Shin CM, Park YS, Lee DH. Annual eradication rate of bismuth-containing quadruple therapy as secondline treatment for Helicobacter pylori infection: A 15-year prospective study at a tertiary hospital in Korea.Helicobacter. 2020;25(3):e12685. doi: 10.1111/hel.12685.

2. Fischbach W. Peter Malfertheiner. Helicobacter Pylori InfectionDtsch Arztebl Int. 2018;115(25):429-36. doi:10.3238/arztebl.2018.0429.

3. Diaconu S, Predescu A, Moldoveanu A, Pop CS, Fierbințeanu-Braticevici C. Helicobacter Pylori Infection: Old NewJ Med Life. 2017;10(2):112-7..PMID: 28616085.

4. Lahner E, Carabotti M, Annibale B. Treatment of Helicobacter pylori infection in atrophic gastritis. World. J Gastroenterol. 2018;24(22):2373-80. doi:10.3748/wjg.v24.i22.2373.

5. Suzuki S, Esaki M, Kusano C, Ikehara H, Gotoda T. Development of Helicobacter pylori treatment:How do we manage antimicrobial resistance? World J Gastroenterol. 2019;25(16):1907-12. doi:10.3748/wjg.v25.i16.1907.

6. Malfertheiner P, Megraud F, O'Morain CA, Gisbert JP, Kuipers EJ, Axon AT, Bazzoli F, Gasbarrini A, Atherton J, Graham DY, Hunt R, Moayyedi P, Rokkas T, Rugge M, Selgrad M, Suerbaum S, Sugano K, El-Omar EM. European Helicobacter and Microbiota Study Group and Consensus panel. Management of Helicobacter pylori infection-the Maastricht â囚a/Florence Consensus Report. Gut,2017;66 (1): 6-30. DOI: 10.1136/gutjnl-2016-312288.

7. Savoldi A, Carrara E, Graham DY, Conti M, Tacconelli E. Prevalence of Antibiotic Resistance in Helicobacter pylori: A Systematic Review and Meta-analysis in World Health Organization Regions. Gastroenterology, 2018;155(5): 1372-82. DOI: 10.1053/j.gastro. 2018.07.007.

8. Liu DS, Wang YH, Zeng ZR, Zhang ZY, Lu H, Xu JM, Du YQ, Li Y, Wang JB, Xu SP, Chen Y, Lan CH, Cheng H, Jiang MD, Zhang LX, Huo LJ, Chen SY, Zhang GX, Wu KC, Zhu X, Chen YX, Zhu Y, Shu X, Xie Y, Lu NH. Primary antibiotic resistance of Helicobacter pylori in Chinese patients: a multiregion prospective 7-year study[J]. Clin Microbiol Infect. 2018;24(7):780. DOI:10.1016/j.cmi.2017.11.010. e5-780.e8.

9. Ge X, Cai Y, Chen Z, Gao S, Geng X, Li Y, Li Y, Jia J, Sun Y. Bifunctional Enzyme SpoT Is Involved in Biofilm Formation of Helicobacter pylori with Multidrug Resistance by Upregulating Efflux Pump Hp1174 (gluP).Antimicrob Agents Chemother. 2018;62(11):e00957-18. doi: 10.1128/AAC.00957-18.

10. Bińkowska A, Biernat MM, Łaczmański Ł, Gościniak G. Molecular Patterns of Resistance Among Helicobacter pylori Strains in SouthWestern Poland. Front Microbiol. 2018;9:3154. doi:10.3389/fmicb.2018.03154.

11. Zhang XY, Shen WX, Chen CF, Sheng HH, Cheng H, Li J, Hu F, Lu DR, Gao HJ. Detection of the clarithromycin resistance of Helicobacter pylori in gastric mucosa by the amplification refractory mutation system combined with quantitative real-time. PCRCancer Med. 2019;8(4):1633-40. doi:10.1002/cam4.1986.

12. Matta AJ, Zambrano DC, Pazos AJ. Punctual mutations in 23S rRNA gene of clarithromycin resistant Helicobacter pylori in Colombian populations. World J Gastroenterol. 2018;24(14):1531-9. doi:10.3748/wjg.v24.i14.1531.

13. Alarcón-Millán J, Fernández-Tilapa G, Cortés-Malagón EM, Castañón-Sánchez CA, De Sampedro-Reyes J, Cruz-Del Carmen I, BetancourtLinares R, Román-Román A. Clarithromycin resistance and prevalence of Helicobacter pylori virulent genotypes in patients from Southern México with chronic gastritis. Infect Genet Evol. 2016;44:190-8. doi: 10.1016/j.meegid. 2016.06.044.

14. Kouitcheu Mabeku LB, Eyoum Bille B, Tepap Zemnou C, Tali Nguefack LD, Leundji H.Broad spectrum resistance in Helicobacter pylori isolated from gastric biopsies of patients with dyspepsia in Cameroon and efflux-mediated multiresistance detection in MDR isolates.BMC Infect Dis. 2019;19(1):880. doi: 10.1186/s12879-019-4536-8.

15. Attaran B, Falsafi T, Ghorbanmehr N. Effect of biofilm formation by clinical isolates of Helicobacter pylori on the efflux-mediated resistance to commonly used antibiotics. World J Gastroenterol. 2017 Feb 21;23(7):1163-1170. doi: 10.3748/wjg.v23.i7.1163.

16. Su P, Li Y, Li H, Zhang J, Lin L, Wang Q, Guo F, Ji Z, Mao J, Tang W, Shi Z, Shao W, Mao J, Zhu X, Zhang X, Tong Y, Tu H, Jiang M, Wang Z. Fengzhe Jin, Ningmin Yang, Jianzhong Zhang. Antibiotic resistance of Helicobacter pylori isolated in the Southeast Coastal Region of 
China. Helicobacter. 2013;18:274-9. doi:10.1111/hel.12046.

17. Ranjbar R, Farsani FY, Dehkordi FS. Phenotypic analysis of antibiotic resistance and genotypic study of the vacA, cagA, iceA, oipA and babA genotypes of the Helicobacter pylori strains isolated from raw milk. Antimicrob Resist Infect Control. 2018 Sep 29;7:115. doi:

10.1186/s13756-018-0409-y.

18. Humphries RM, Kircher S, Ferrell A, Krause KM, Malherbe R, Hsiung A, Burnham CA. The Continued Value of Disk Diffusion for Assessing Antimicrobial Susceptibility in Clinical Laboratories: Report from the Clinical and Laboratory Standards Institute Methods Development and Standardization Working Group. J Clin Microbiol. 2018 Jul 26;56(8):e00437-18. doi: 10.1128/JCM.00437-18.

19. Goderska K, Agudo Pena S, Alarcon T. Helicobacter pylori treatment: antibiotics or probiotics.Appl Microbiol Biotechnol. 2018 Jan;102(1):1-7. doi: 10.1007/s00253-017-8535-7.

20. Thung I, Aramin H, Vavinskaya V, Gupta S, Park JY, Crowe SE, Valasek MA. Review article: the global emergence of Helicobacter pylori antibiotic resistance. Aliment Pharmacol Ther. 2016 Feb;43(4):514-33. doi:10.1111/apt.13497.

21. Munita JM, Arias CA.Mechanisms of Antibiotic Resistance.Microbiol Spectr. 2016;4(2):10.1128.doi:10.1128/microbiolspec. VMBF-00162015.

22. Lee CR, Lee JH, Park M, Park KS, Bae IK, Kim YB, Cha CJ, Jeong BC, Lee SH. Biology of Acinetobacter baumannii: Pathogenesis, Antibiotic Resistance Mechanisms, and Prospective Treatment Options. Front Cell Infect Microbiol. 2017 Mar 13;7:55. doi: 10.3389/fcimb.2017.00055.

23. Pang Z, Raudonis R, Glick BR, Lin TJ, Cheng Z. Antibiotic resistance in Pseudomonas aeruginosa: mechanisms and alternative therapeutic strategies.Biotechnol Adv. 2019 Jan-Feb;37(1):177-192. doi: 10.1016/j.biotechadv.2018.11.013.

24. Chung The H, Baker S. Out of Asia: the independent rise and global spread of fluoroquinolone-resistant Shigella. Microb Genom. 2018;4(4):e000171.doi: 10.1099/ mgen.0.000171.

25. Tahereh Falsafi A, Ehsani B, Attaran, Niknam V. Association of hp1181 and hp1184 Genes With the Active Efflux Phenotype in MultidrugResistant Isolates of Helicobacter pylori. Jundishapur J Microbiol. 2016;9(4):e30726. doi:10.5812/jjm.30726.

26. Karin van Amsterdam, A, Bart, Arie, van der Ende. A Helicobacter pylori TolC Efflux Pump Confers Resistance to Metronidazole. Antimicrob Agents Chemother. 2005;49(4):1477-82. doi:10.1128/AAC.49.4.1477-1482.2005.

\section{Tables}

Table 1 Drug resistance characteristics of three drug-resistant strains (MIC: $\mu \mathrm{g} / \mathrm{ml}$ )

\begin{tabular}{|lllll|}
\hline strains & Metronidazole & Clarithromycin & Levofloxacin & Amoxicillin \\
\hline Hpbs1 & 32 & 8 & 8 & 0.125 \\
\hline Hpbs2 & 16 & 8 & 0.125 & 0.125 \\
\hline Hpbs3 & 0.125 & 8 & 8 & 0.125 \\
\hline
\end{tabular}

Table 2 Sequence information of three drug-resistant strains

\begin{tabular}{|c|c|c|c|c|c|c|}
\hline $\begin{array}{l}\text { Sample } \\
\text { Name }\end{array}$ & ID Name & $\begin{array}{l}\text { Sequence } \\
\text { Type( }(1)\end{array}$ & $\begin{array}{l}\text { Sequence } \\
\text { Topology }\end{array}$ & $\begin{array}{l}\text { Sequence } \\
\text { Number( }(0)\end{array}$ & $\begin{array}{l}\text { Total Length } \\
\text { (bp) }\end{array}$ & $\begin{array}{l}\text { GC Content } \\
\text { (\%) }\end{array}$ \\
\hline \multirow[t]{2}{*}{ Њpos1 } & Chromosome1 & Chromosome & circular & 1 & $1,563,701$ & 38.90 \\
\hline & All & All & . & 1 & $1,563,701$ & 38.90 \\
\hline \multirow[t]{2}{*}{ Hobs2 } & Chromosome1 & Chromosome & circular & 1 & $1,534,481$ & 38.87 \\
\hline & All & All & - & 1 & $1.534,481$ & 38.87 \\
\hline \multirow[t]{2}{*}{ Hos 3 } & Chromosome1 & Chromosome & circular & 1 & $1.534,930$ & 38.90 \\
\hline & All & All & - & 1 & 1.534 .930 & 38.90 \\
\hline
\end{tabular}

Note: Sequence Type, chromosome or plasmid;Sequence Topology, circular or linear.

Table 3 The gene information of three drug-resistant strains

\begin{tabular}{|c|c|c|c|c|c|c|}
\hline $\begin{array}{l}\text { Sample Name } \\
\text { (i) }\end{array}$ & $\begin{array}{l}\text { Genome Size } \\
\text { (i) }\end{array}$ & $\begin{array}{l}\text { Total Number } \\
\text { (ii) }\end{array}$ & $\begin{array}{l}\text { Total Length } \\
\text { (bp) }\end{array}$ & $\begin{array}{l}\text { Average Length } \\
\text { (ii) }\end{array}$ & $\begin{array}{l}\text { Length / Genome } \\
\text { Length (\$) }\end{array}$ & $\begin{array}{l}\text { GC Content } \\
\text { (\%) }\end{array}$ \\
\hline Hpbs1 & $1,563,701$ & 1.571 & $1,434,204$ & 912.92 & 91.72 & 39.49 \\
\hline Hpbs2 & $1,534,481$ & 1,792 & $1,395,399$ & 778.68 & 90.94 & 39.44 \\
\hline Hpbs3 & $1,534,930$ & 1,732 & $1,407,495$ & 812.64 & 91.70 & 39.49 \\
\hline
\end{tabular}

Note: Total Number,the count of genes; Total Length,total length of all genes; Average Length,average length of all genes: GC Content, the content of $\mathrm{G}$ and $\mathrm{C}$ in gene; Length/Genome Length, The proportion of gene length in genome. 


\begin{tabular}{|c|c|c|c|c|c|c|c|c|c|c|}
\hline $\begin{array}{l}\text { Sample } \\
\text { Name }(M)\end{array}$ & $\begin{array}{l}\text { Total } \\
\text { (i) }\end{array}$ & $\begin{array}{l}\text { P450 } \\
\text { (i) }\end{array}$ & VFDB $(n)$ & $\begin{array}{l}\text { ARDB } \\
(\mathbb{A})\end{array}$ & $\begin{array}{l}\text { CAZY } \\
\text { (A) }\end{array}$ & $\begin{array}{l}\text { SWISSPROT } \\
\text { (t) }\end{array}$ & NOG $(M)$ & $\cos (\theta)$ & $\begin{array}{l}\text { CARD } \\
\text { (i) }\end{array}$ & NR $(M)$ \\
\hline Hpbs1 & 1.571 & $\begin{array}{l}22 \\
(1.4 \%)\end{array}$ & $\begin{array}{l}196 \\
(12.47 \%)\end{array}$ & $\begin{array}{l}0 \\
(0 \%)\end{array}$ & $\begin{array}{l}14 \\
(0.899 \%)\end{array}$ & $\begin{array}{l}742 \\
(47.23 \%)\end{array}$ & $\begin{array}{l}67 \\
(4.26 \%)\end{array}$ & $\begin{array}{l}1.084 \\
(69 \%)\end{array}$ & $\begin{array}{l}14 \\
(0.8996)\end{array}$ & $\begin{array}{l}1.559 \\
(99.2396)\end{array}$ \\
\hline Hpbs2 & 1.792 & $\begin{array}{l}21 \\
(1.17 \%)\end{array}$ & $\begin{array}{l}177 \\
(9.87 \%)\end{array}$ & $\begin{array}{l}0 \\
\text { (096) }\end{array}$ & $\begin{array}{l}14 \\
(0.7896)\end{array}$ & $751(41.9 \%)$ & $\begin{array}{l}125 \\
(6.9796)\end{array}$ & $\begin{array}{l}1,111 \\
\text { (61.99\%) }\end{array}$ & $\begin{array}{l}13 \\
(0.72 \%)\end{array}$ & $\begin{array}{l}1,723 \\
(96.14 \%)\end{array}$ \\
\hline Hpbs3 & 1,732 & $\begin{array}{l}22 \\
(1.27 \%)\end{array}$ & $\begin{array}{l}174 \\
(10.04 \%)\end{array}$ & $\begin{array}{l}0 \\
\text { (0\%) }\end{array}$ & $\begin{array}{l}13 \\
(0.7596)\end{array}$ & $750(43.396)$ & $\begin{array}{l}97 \\
(5.6 \%)\end{array}$ & $\begin{array}{l}1.113 \\
(64.26 \%)\end{array}$ & $\begin{array}{l}15 \\
(0.86 \%)\end{array}$ & $\begin{array}{l}1.698 \\
(98.03 \%)\end{array}$ \\
\hline
\end{tabular}

Table 5 Gene annotation statistics B

\begin{tabular}{|c|c|c|c|c|c|c|c|c|c|}
\hline $\begin{array}{l}\text { Sample } \\
\text { Name }(i)\end{array}$ & $\begin{array}{l}\text { DBCAN } \\
\text { (i) }\end{array}$ & T3SS (A) & $\begin{array}{l}\text { TREMBL } \\
\text { (ii) }\end{array}$ & IPR $(\omega)$ & PHI $(\mu)$ & KEGG $(M)$ & $G O\left(^{(n)}\right)$ & KOG $(\theta)$ & OverAll ( $(A)$ \\
\hline Hpbs1 & $\begin{array}{l}30 \\
(1.9 \%)\end{array}$ & $\begin{array}{l}175 \\
\text { (11.1396) }\end{array}$ & $\begin{array}{l}1.557 \\
(99.1 \%)\end{array}$ & $\begin{array}{l}1.234 \\
(78.5496)\end{array}$ & $\begin{array}{l}54 \\
(3.4396)\end{array}$ & $\begin{array}{l}1.026 \\
(65.3 \%)\end{array}$ & $\begin{array}{l}957 \\
(60.91 \%)\end{array}$ & $\begin{array}{l}142 \\
(9.03 \%)\end{array}$ & $\begin{array}{l}1.563 \\
(99.49 \%)\end{array}$ \\
\hline Hpbs2 & $\begin{array}{l}29 \\
(1.61 \%)\end{array}$ & $\begin{array}{l}197 \\
(10.99 \%)\end{array}$ & $\begin{array}{l}1.706 \\
(95.2 \%)\end{array}$ & $\begin{array}{l}1,372 \\
(76.56 \%)\end{array}$ & $\begin{array}{l}52 \\
(2.9 \%)\end{array}$ & $\begin{array}{l}1.078 \\
(60.15 \%)\end{array}$ & $\begin{array}{l}1.056 \\
(58.9296)\end{array}$ & $\begin{array}{l}144 \\
(8.03 \%)\end{array}$ & $\begin{array}{l}1,750 \\
(97.65 \%)\end{array}$ \\
\hline Hpbs3 & $\begin{array}{l}30 \\
(1.7396)\end{array}$ & $\begin{array}{l}209 \\
(12.06 \%)\end{array}$ & $\begin{array}{l}1.688 \\
(97.45 \%)\end{array}$ & $\begin{array}{l}1,340 \\
(77.36 \%)\end{array}$ & $\begin{array}{l}51 \\
(2.94 \%)\end{array}$ & $\begin{array}{l}1.067 \\
(61.6 \%)\end{array}$ & $\begin{array}{l}1.030 \\
(59.46 \%)\end{array}$ & $\begin{array}{l}139 \\
(8.02 \%)\end{array}$ & $\begin{array}{l}1,711 \\
(98.78 \%)\end{array}$ \\
\hline
\end{tabular}

Table 6 Analysis of gene resistance in CARD

\begin{tabular}{|c|c|c|c|c|c|c|c|c|c|}
\hline Gene_id & Subject_id & Align_length & Mismatch & Gap & Gene_start & Gene_end & Subject_start & Subject_end & E_value \\
\hline GL000175 & YP_208874.1 & 97 & 39 & 0 & 2 & 98 & 4 & 100 & $\begin{array}{l}6.00 \mathrm{E}- \\
40\end{array}$ \\
\hline GL000286 & YP_006374661.1 & 398 & 88 & 2 & 1 & 397 & 29 & 421 & 0 \\
\hline GL000295 & NP_312937.1 & 1389 & 658 & 21 & 8 & 1371 & 8 & 1339 & 0 \\
\hline GL000296 & AAK44936.1 & 124 & 35 & 0 & 1 & 124 & 1 & 124 & $\begin{array}{l}4.00 \mathrm{E}- \\
63\end{array}$ \\
\hline GL000306 & NP_207975.1 & 459 & 16 & 0 & 1 & 459 & 1 & 459 & 0 \\
\hline GL000309 & NP_207972.1 & 443 & 10 & 0 & 1 & 443 & 1 & 443 & 0 \\
\hline GL000772 & AlL15701 & 421 & 220 & 3 & 1 & 420 & 1 & 417 & $\begin{array}{l}4.00 \mathrm{E}- \\
126\end{array}$ \\
\hline GL000822 & YP_002344422.1 & 853 & 293 & 6 & 3 & 818 & 2 & 851 & 0 \\
\hline GL000911 & NP_415611.1 & 247 & 130 & 2 & 1 & 247 & 1 & 243 & $\begin{array}{l}2.00 \mathrm{E}- \\
66\end{array}$ \\
\hline GL000972 & WP_005768149.1 & 810 & 390 & 18 & 3 & 773 & 12 & 809 & 0 \\
\hline GL001063 & AJF83452.1 & 287 & 164 & 2 & 1 & 283 & 2 & 288 & $\begin{array}{l}1.00 \mathrm{E}- \\
71\end{array}$ \\
\hline GL001265 & NP_415804.1 & 262 & 141 & 1 & 1 & 261 & 1 & 262 & $\begin{array}{l}2.00 \mathrm{E}- \\
80\end{array}$ \\
\hline GL001295 & YP_001332362.1 & 222 & 123 & 4 & 1 & 221 & 1 & 216 & $\begin{array}{l}7.00 \mathrm{E}- \\
51\end{array}$ \\
\hline GL001455 & AJF82049.1 & 254 & 141 & 2 & 4 & 255 & 7 & 260 & $\begin{array}{l}2.00 \mathrm{E}- \\
62\end{array}$ \\
\hline
\end{tabular}

Table 7 Characteristics of drug resistance genes in CARD 


\begin{tabular}{|c|c|c|}
\hline Subject_id & ARO_number & Definition of Term \\
\hline YP_2088741 & Neisseria gonortioe ae FA 1090 & 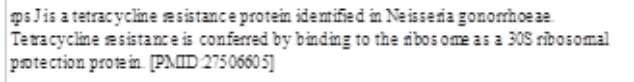 \\
\hline YP_006374661.1 & Enterococeus faeciumDO & $\begin{array}{l}\text { Sequence variants of Enterococcus faecium elongation factor Tu that confer } \\
\text { sesistance to GE2270A [PMDD } 7989561 \text { ] }\end{array}$ \\
\hline NP_312937.1 & Escheichia coli O157H7 str Sabai & $\begin{array}{l}\text { Point mutations that occurs in Es cherichia coli poB res ulting in resis tance to } \\
\text { ifampicin [PNDD 3050121] }\end{array}$ \\
\hline AAR 49361 & $\begin{array}{l}\text { Mycobacterium tuberculosis } \\
\text { CDC1551 }\end{array}$ & 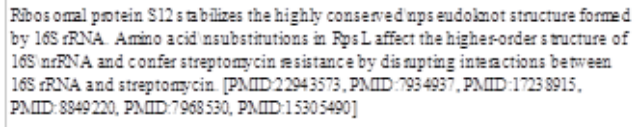 \\
\hline NP_207975.1 & Helicobacter pyloi 26695 & $\begin{array}{l}\text { hp } 1184 \text { is a tanslocase that belongs to the MATE effuxpump famly. If is found in } \\
\text { H pyloriand is involved in the active effux of antibiotics. [PNDD } 27303615 \text {. } \\
\text { PNID: } 15793129 \text { ] }\end{array}$ \\
\hline NP_2079721 & Helicobacter pylod 26695 & $\begin{array}{l}\text { hp } 1181 \text { is a tanslocase that is part of the NFS effuxpunp family. It is found in } \mathrm{H} \\
\text { pylori and has role in the active effux of antibiotics. [PNID 27303615] }\end{array}$ \\
\hline All15701 & Escherichia coli AT $\propto 25922$ & 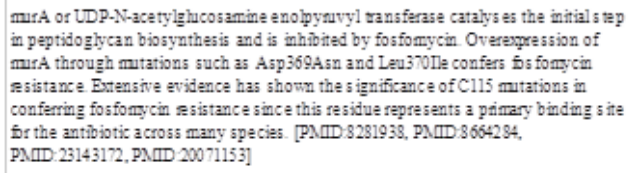 \\
\hline YP_ 0023444221 & $\begin{array}{l}\text { Campylobacter jejuni subsp. jejuni } \\
\text { NCTC11168 }\end{array}$ & $\begin{array}{l}\text { Campylobacter jefuni is a major bacteial infectious agent associated with } \\
\text { gastroenteritis. Quinolone sesistance is sporedly conferred by a singla C-257-T } \\
\text { nuclaotide substitution in the gyrA gene [PM⿻D 26658311] }\end{array}$ \\
\hline NP_4156111 & $\begin{array}{l}\text { Eschesichia colistr. } \mathrm{K}-12 \text { subs tr. } \\
\text { MGG1655 }\end{array}$ & 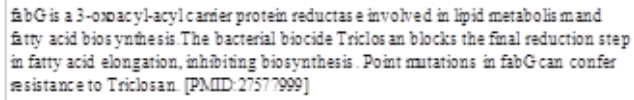 \\
\hline WP_005768149.1 & Bartone la baciliformis KC583 & $\begin{array}{l}\text { Point mutation in Bartonella bacilifornis sesuling in aminocoumarin resis tance } \\
\text { PNID } 9797224 \text { ] }\end{array}$ \\
\hline AJF834521 & Acinetobacter baumannii & $\begin{array}{l}\text { The Ipx gene is widely lnown to be involved in the biosynthesis of lipid A in Gram- } \\
\text { negative bacteria and mutations to this gene may cause res istance to antimicrobial. } \\
\text { peptides that taget the outer me mbrane [PMID 20855724, PMID 24199257] }\end{array}$ \\
\hline NP_415804 1 & $\begin{array}{l}\text { Eschesichia colistr. K-12 subs r. } \\
\text { MGG1655 }\end{array}$ & 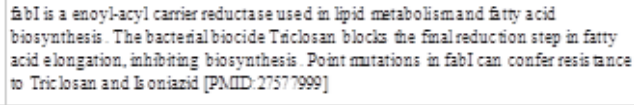 \\
\hline YP_0013323621 & $\begin{array}{l}\text { Staphybococeus aureus subsp. aureus } \\
\text { str Newman }\end{array}$ & $\begin{array}{l}\text { ArR is a response re gulator that binds to the norA promoter to a ctivate expres sion. } \\
\text { ArR must frst be phosphorylated by AsIS. [PNID } 10633099 \text { ] }\end{array}$ \\
\hline AJF32049:1 & Acinetobacter baumannii & 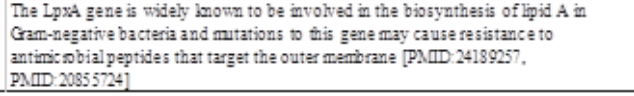 \\
\hline
\end{tabular}

Table 8 Mutations in the 23S rRNA genes of Hp strains

\begin{tabular}{|c|c|c|c|c|c|}
\hline Nucleotide position & Ref & Mutation & Hpbs l & Hpbs2 & Hpbs 3 \\
\hline 2143 & A & G & + & + & + \\
\hline 2142 & A & G & + & + & + \\
\hline 2144 & G & T & + & + & + \\
\hline 2302 & A & G & - & - & + \\
\hline 2182 & T & C & - & + & - \\
\hline 2173 & C & T & + & + & + \\
\hline 1513 & G & A & - & + & + \\
\hline 2196 & C & T & + & - & - \\
\hline 1280 & A & G & + & - & - \\
\hline 1023 & G & A & - & - & + \\
\hline & & & & & + \\
\hline
\end{tabular}

Table 9 23S rRNA mutations of Hp strains

\section{$\begin{array}{lllll}\text { Nucleotide position } & \text { Ref } & \text { Mutation } & \text { 26695(S) } & \text { 26695(R) }\end{array}$}

\begin{tabular}{|l|l|l|l|l|}
\hline 2142 & A & G & - & + \\
\hline 2143 & A & G & - & + \\
\hline
\end{tabular}

\section{Figures}



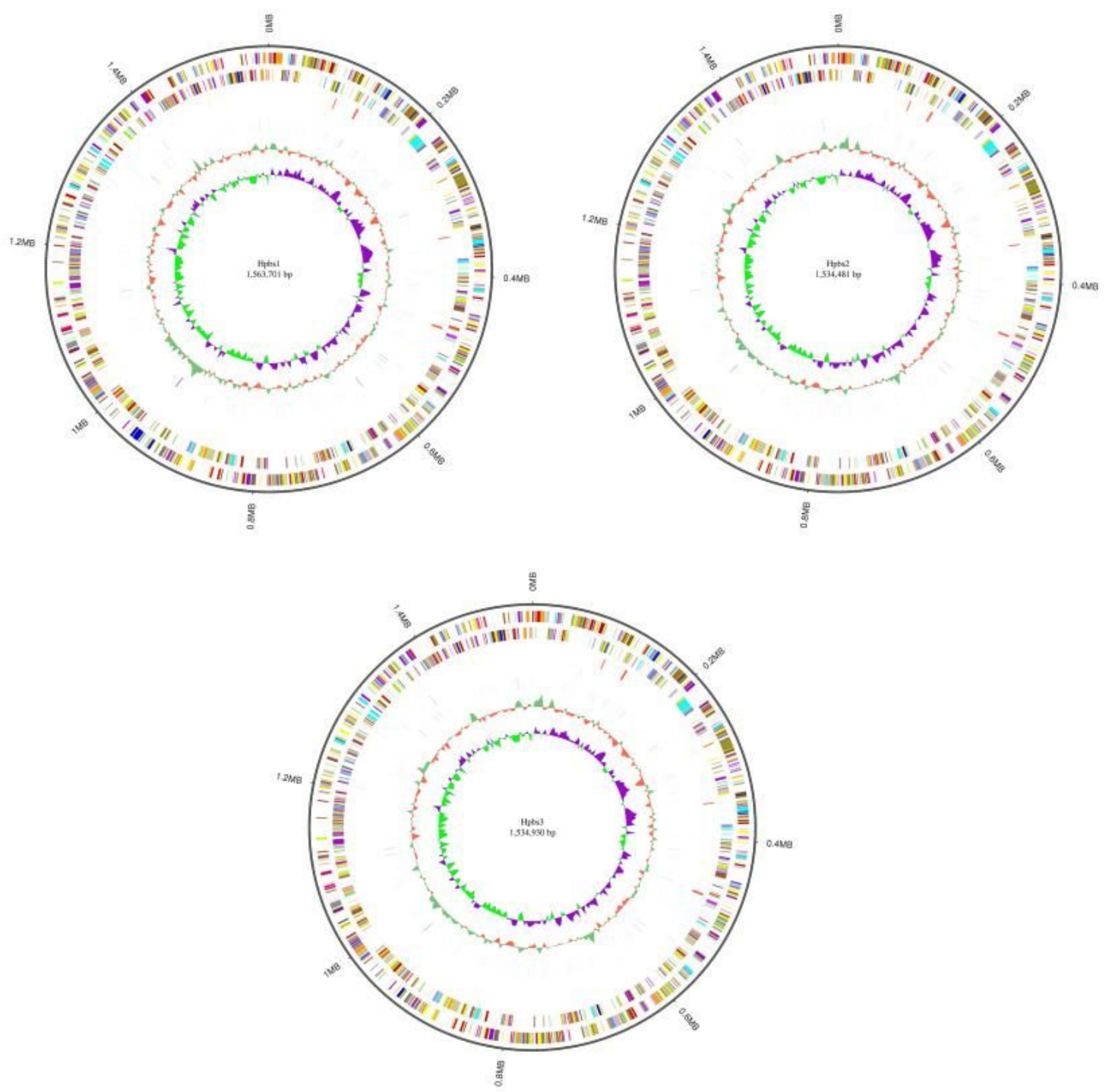

\section{Figure 1}

The circular genome analysis of three resistant strains. A. Hpbs1; B. Hpbs2; C. Hpbs3. 

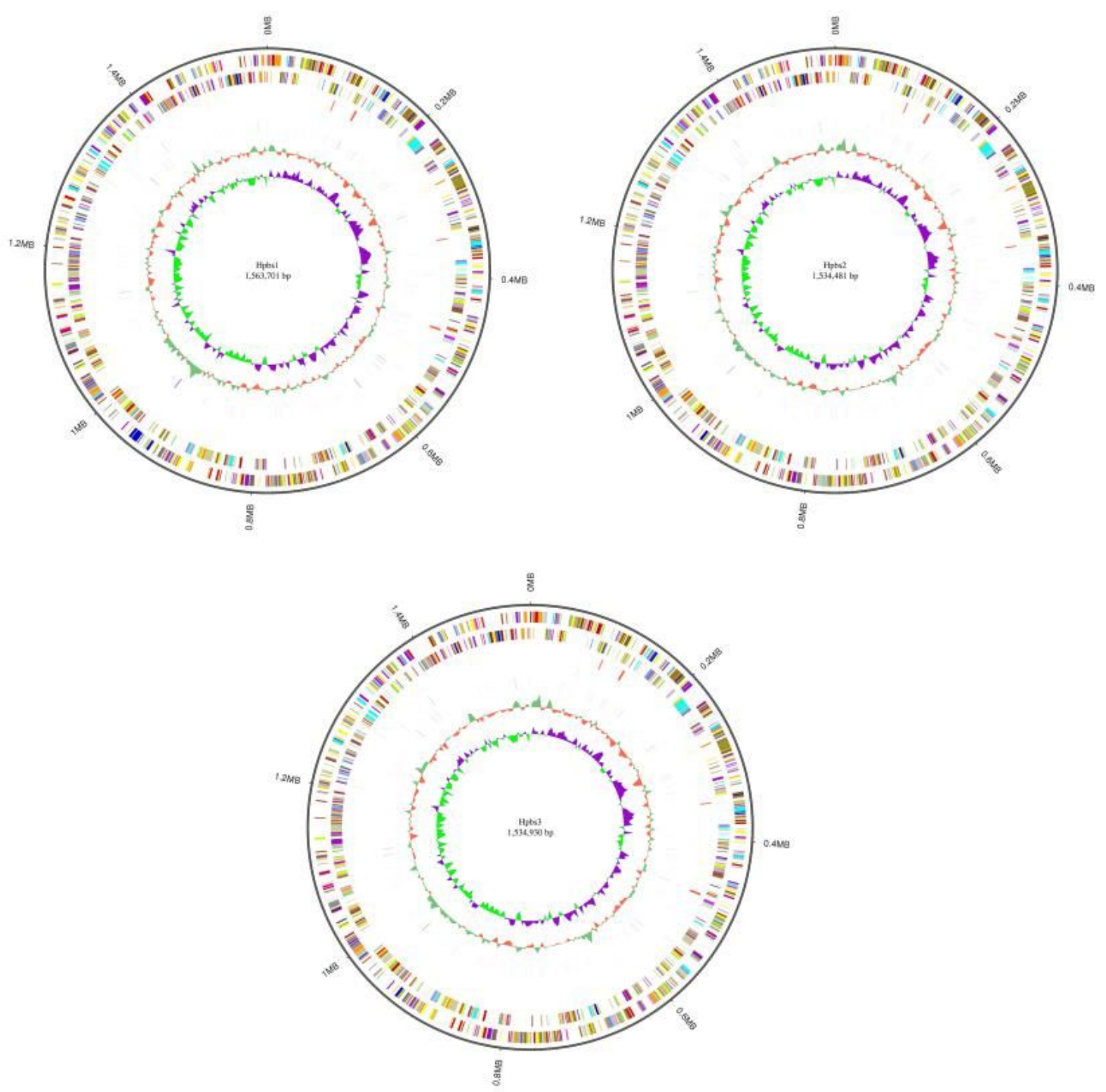

Figure 1

The circular genome analysis of three resistant strains. A. Hpbs1; B. Hpbs2; C. Hpbs3.
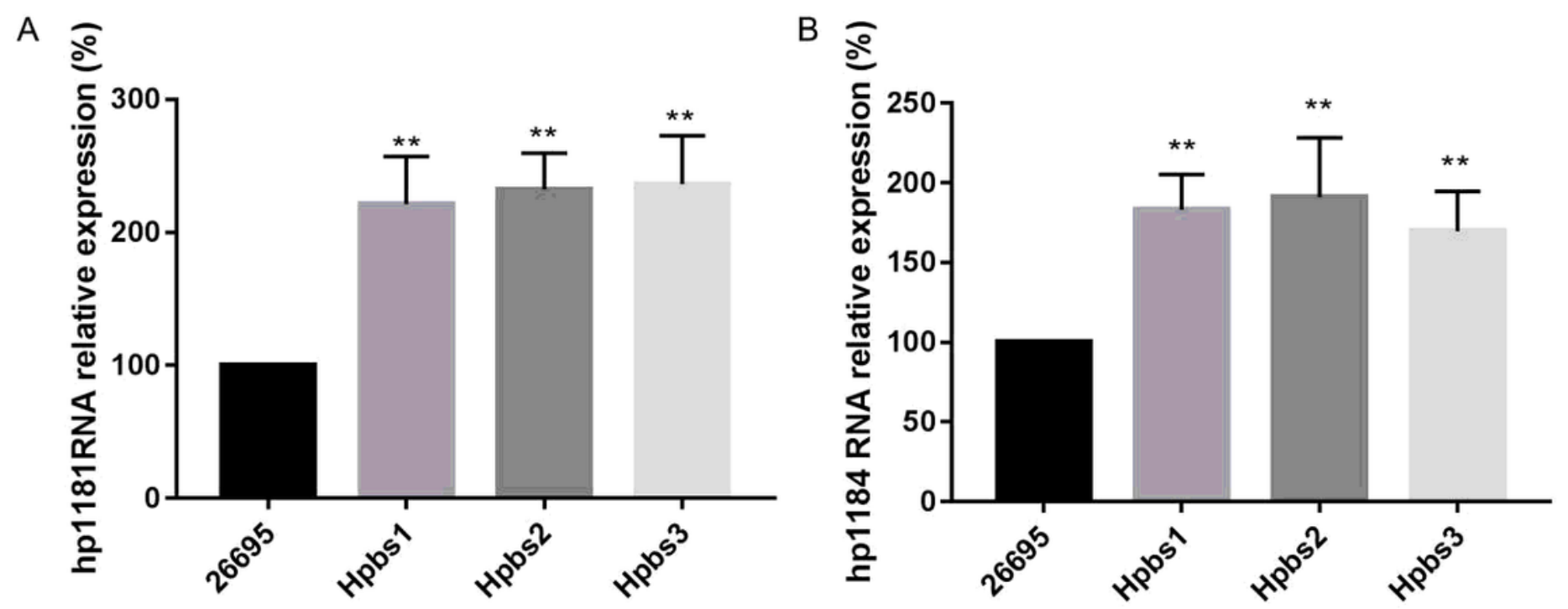

Figure 2 

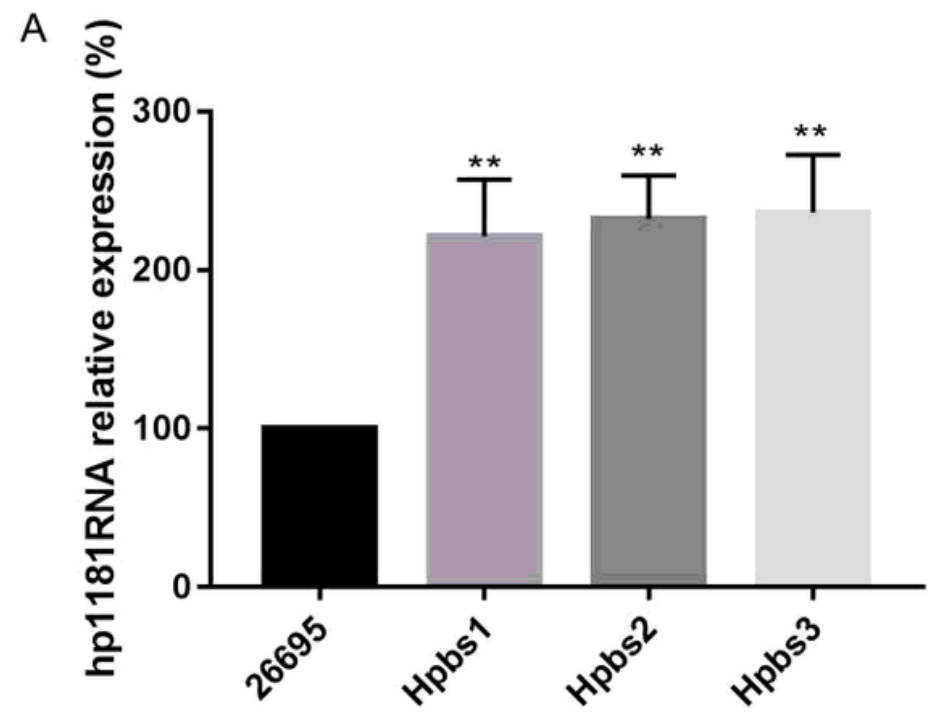

B §

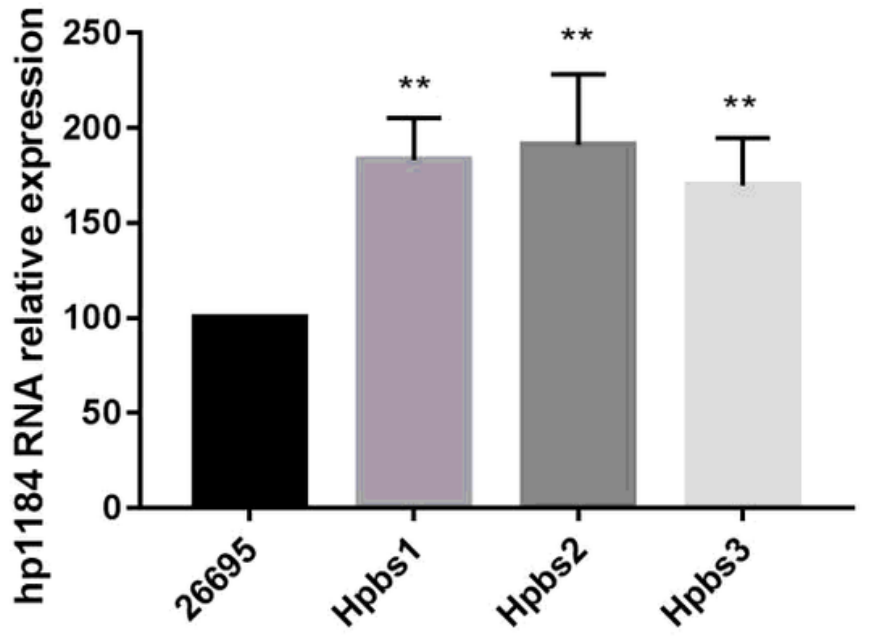

Figure 2

hp1181 and hp1184 gene expressions in drug-resistant strains. A. hp1181; B. hp1184.

$A$ ळ

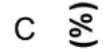
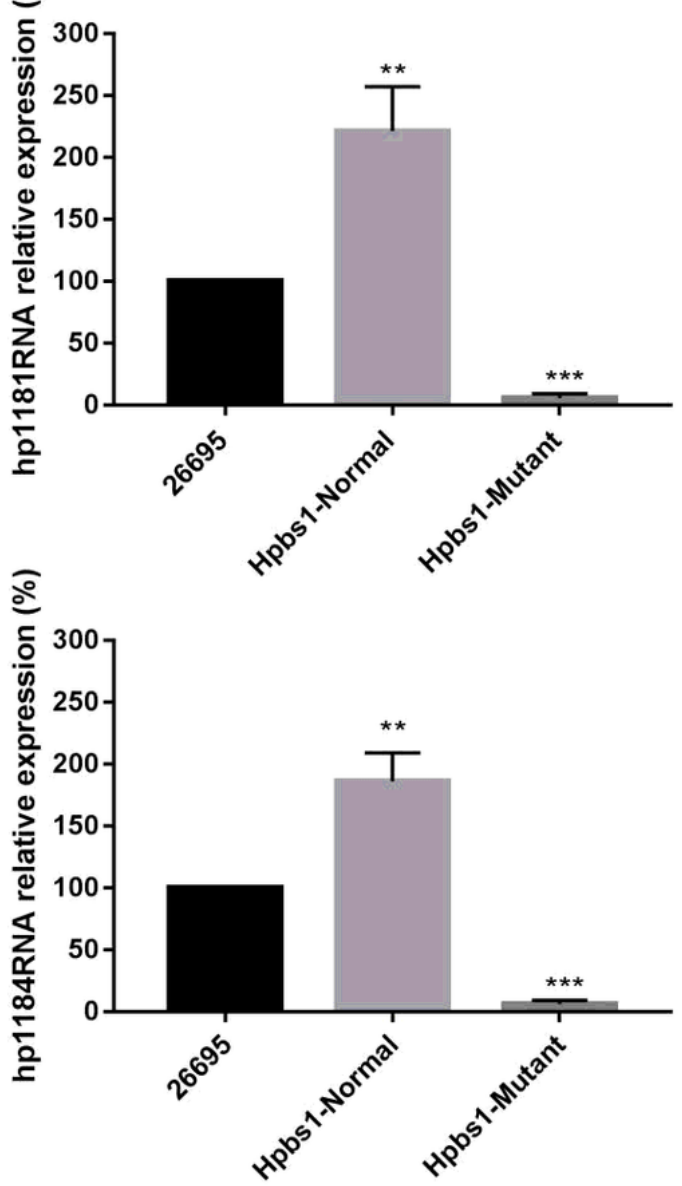

B

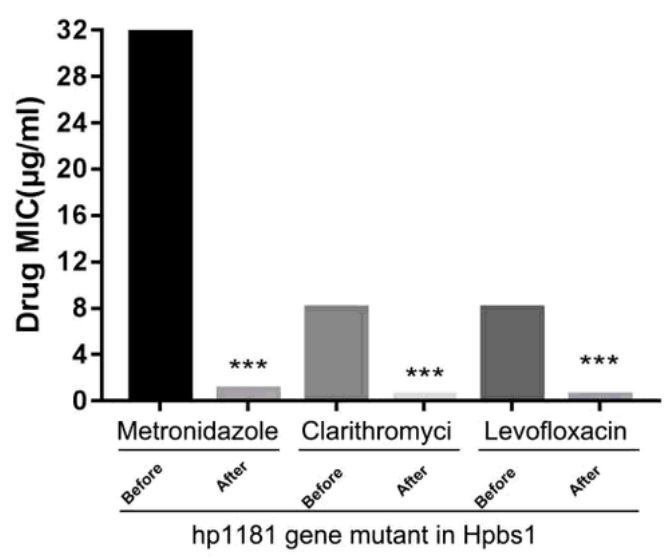

D

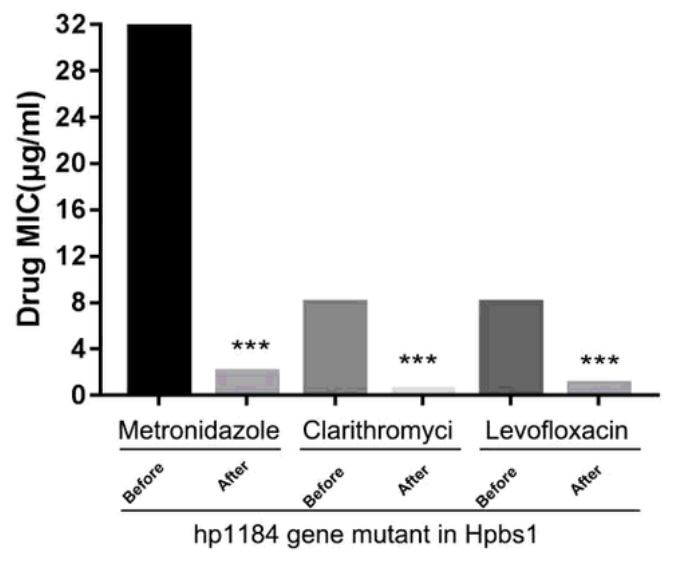


Figure 3

Drug sensitivity was improved after knockout of the drug resistance genes. A. hp1181 knocked out; B. MIC after hp1181 knocked out; C. hp1184 knocked out; D. MIC after hp1184 knocked out.

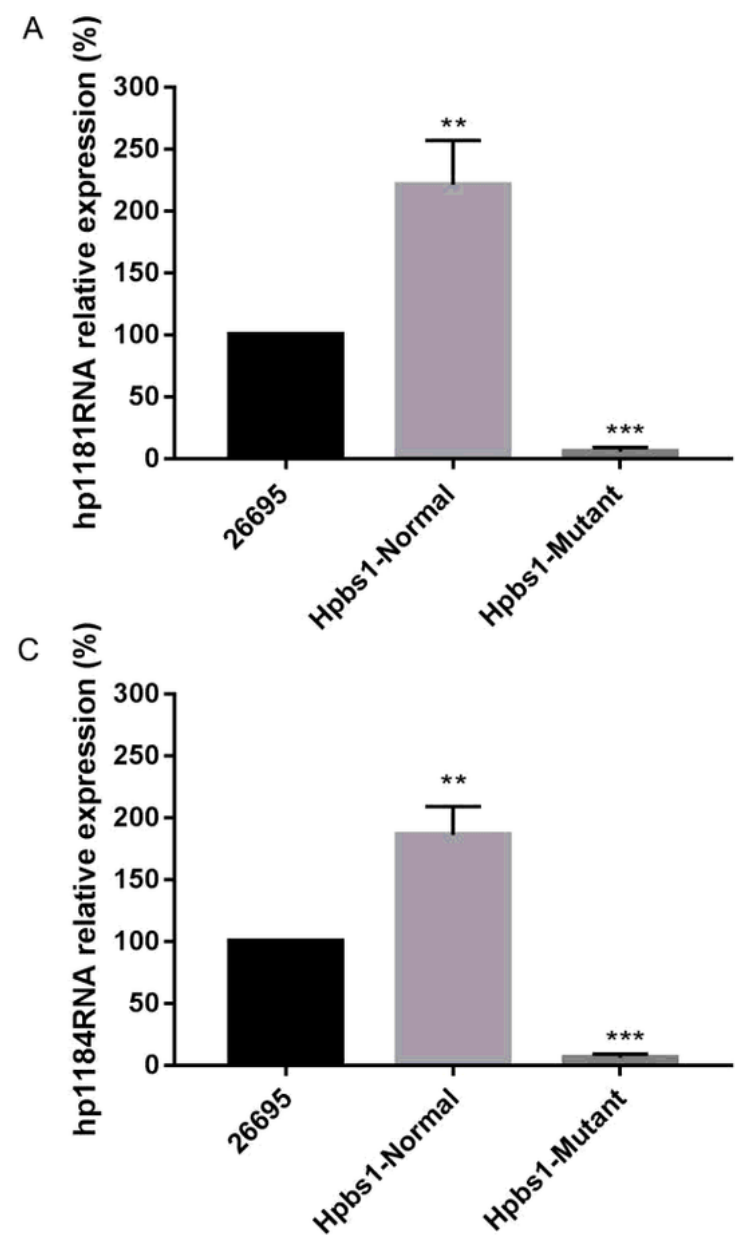

B

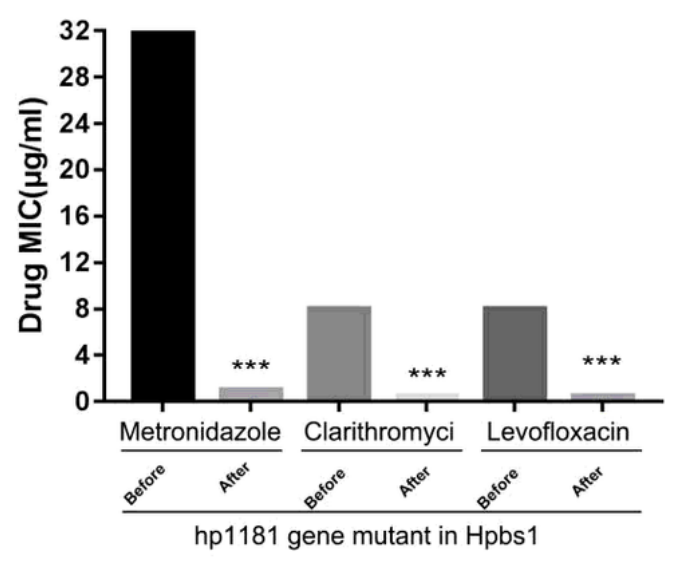

D

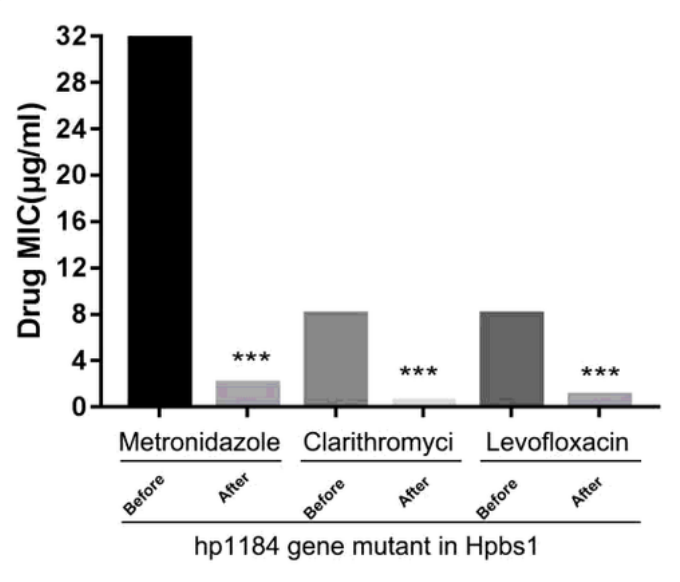

Figure 3

Drug sensitivity was improved after knockout of the drug resistance genes. A. hp1181 knocked out; B. MIC after hp1181 knocked out; C. hp1184 knocked out; D. MIC after hp1184 knocked out. 
A

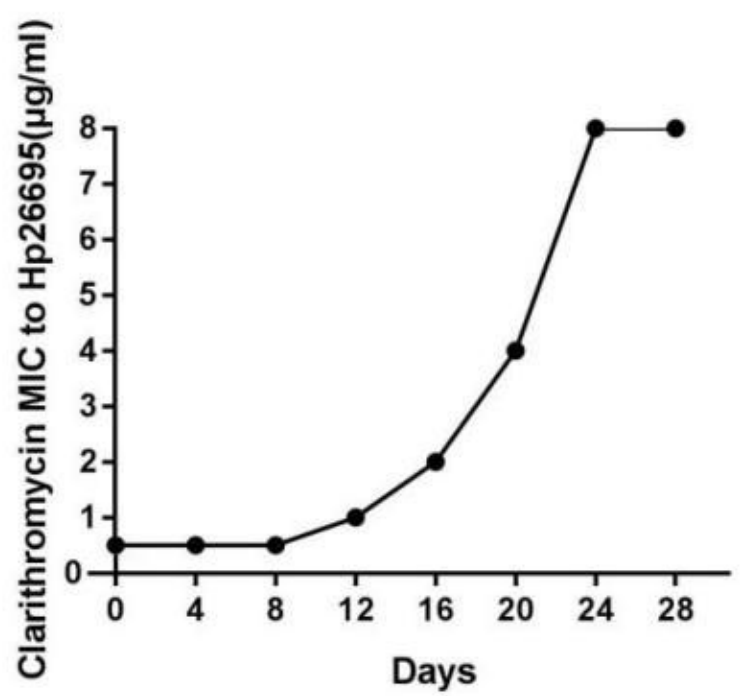

B

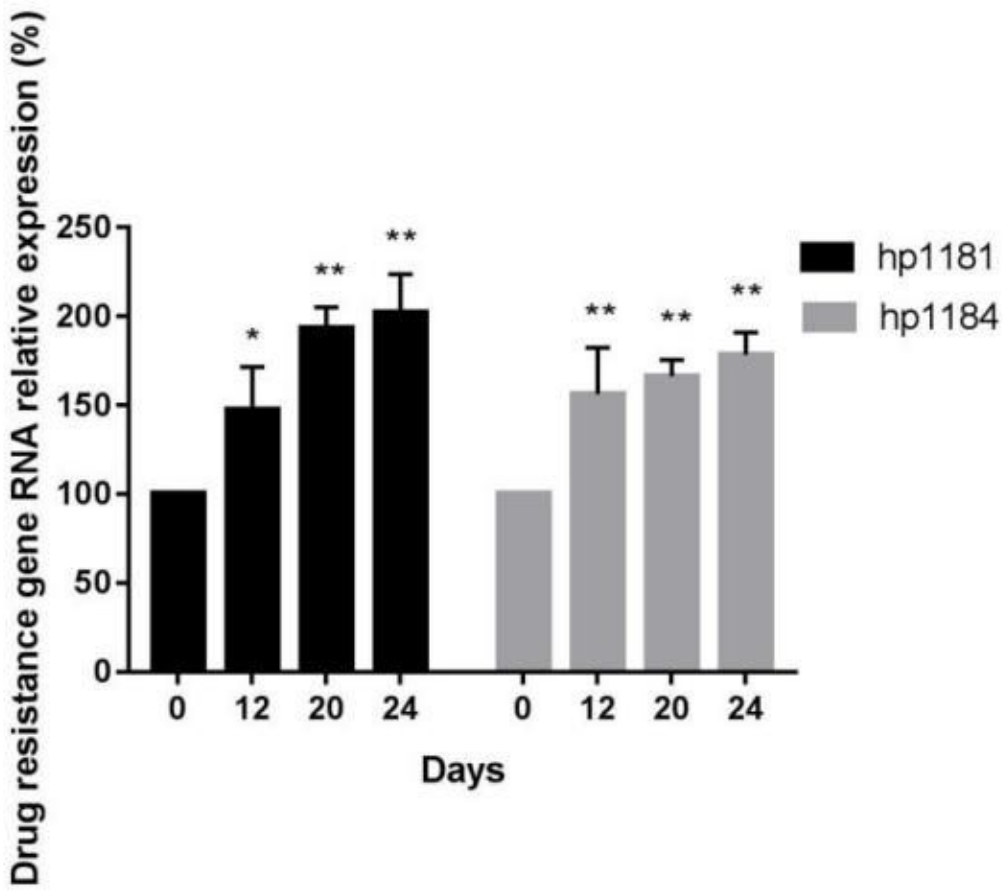

Figure 4

Induction of resistance to clarithromycin and expression of drug resistance genes in $\mathrm{Hp}$. A. Induction of clarithromycin resistance; $\mathrm{B}$. Expression of drug resistance gene.

A

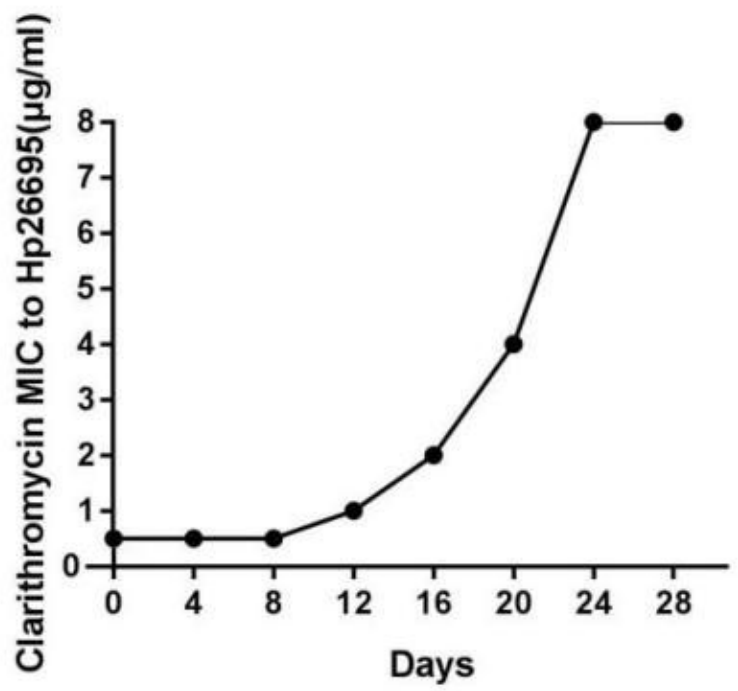

B

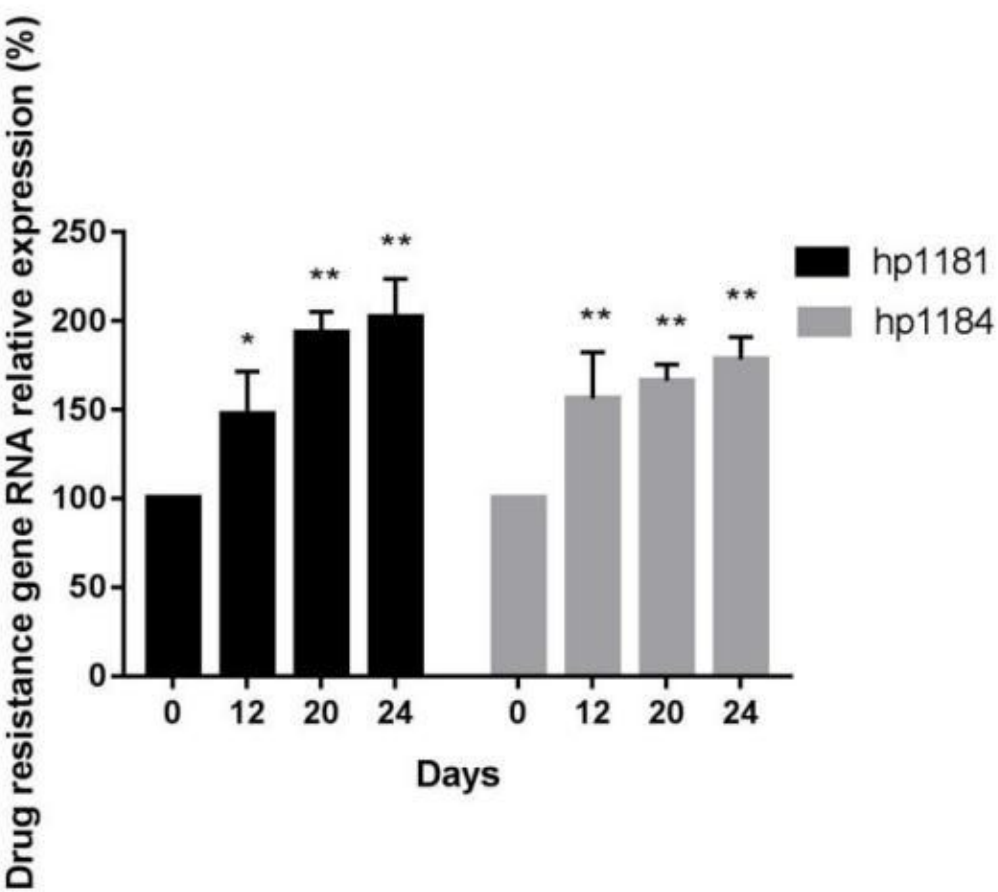

Figure 4

Induction of resistance to clarithromycin and expression of drug resistance genes in $\mathrm{Hp}$. A. Induction of clarithromycin resistance; $\mathrm{B}$. Expression of drug resistance gene. 